\title{
O PROCESSO EXPIATÓRIO de $A$ ROSa do povo, de Carlos Drummond de ANDRADE
}

LeandRo PasinI

Universidade Federal de São Paulo

\section{Resumo}

Este ensaio tem como objetivo estudar o tema da expiação ritual em A rosa do povo (1945), de Carlos Drummond de Andrade, por meio de cortes transversais temáticos na obra. Desse modo, culpa e autodestruição ritual, expiação noturna e morte e vida das palavras se configuram como uma perspectiva de leitura sobre o significado do sujeito lírico, do tempo e da metapoesia no livro, respectivamente. Com isso, busca-se interpretar a relação entre engajamento social e reflexão sobre a forma poética em A rosa do povo no contexto da poesia modernista brasileira.

\section{Abstract}

This article aims at studying the theme of ritual atonement in Carlos Drummond de Andrade's A rosa do povo (1945) through a cross-sectional analysis of the work. Thereby, guilt and ritual self-destruction, nocturnal atonement, and death and life of words are set as a reading perspective about the significance of the lyrical subject, time, and metapoetry, respectively. Thus, this article searches to interpret the relation between social commitment and reflection on poetic form in A rosa do povo in the context of Brazilian modernist poetry.

\section{Palavras-chave}

Carlos Drummond de Andrade, A rosa do povo, poesia modernista, modernismo brasileiro, lírica e sociedade, culpa social.

\section{Keywords}

Carlos Drummond de Andrade, A rosa do povo, modernist poetry, Brazilian modernism, lyric poetry and society, social guilt. 
... a poesia parece desfazer-se como registro para
tornar-se um processo, justificado na medida em
que institui um objeto novo, elaborado à custa da
desfiguração, ou mesmo destruição ritual do ser e do
mundo, para refazê-los no plano estético.

A. Candido. "Inquietudes na Poesia de Drummond"

Pôr fogo em tudo, inclusive em mim. Drummond. "A flor e a náusea"

Em A rosa do povo, livro de poemas de 1945, Carlos Drummond de Andrade intensifica, ao mesmo tempo, o engajamento social e a reflexão sobre a forma poética e a natureza da poesia. Desse encontro excepcional entre a perspectiva revolucionária e a aguda consciência metapoética deriva a rica variedade temática e formal que compõe a coletânea. A diversidade formal pode ser verificada na alternância entre o verso livre e o metrificado na composição dos poemas. Embora predomine o verso livre em 25 dos 55 poemas do livro, o poeta utiliza a redondilha menor com frequência ("Carrego comigo", “Áporo", "Assalto", por exemplo), o hexassílabo em "O elefante", bem como usa regularmente a redondilha maior ("Desfile", "Cidade prevista" etc.), o octossílabo em "Retrato de família", o decassílabo branco em alguns poemas, a exemplo de "Versos à boca da noite" e "Visão 1944", e o verso de doze sílabas, por vezes alexandrinos, predomina em "Equívoco". A essa gama de ritmos se soma a variação de registros de linguagem, não apenas alternando a dicção dos versos mas também misturando-os em casos como "Minhas filhas, boca presa./Vosso pai evém chegando" ("Caso do vestido"), "nutrindo-me de Petrarca,/Ronsard, Camões e Capim” (“O mito”), "No mundo, tamanho peso/de angústia/e você, girafa, tentando" (“Onde há pouco falávamos”).

De modo complementar, demonstrando os recursos expressivos de Drummond, as imagens insólitas estão disseminadas por todo o livro; o poeta gera aproximações imprevistas, significados enigmáticos, ambientações soturnas, grotescas ou eufóricas, criando um tipo de aproveitamento pessoal, particular e original, dos procedimentos surrealistas. Por fim, a enumeração caótica comparece na coletânea de ponta a ponta, agrupando os elementos heterogêneos que tanto podem compor esse universo imagético quanto inserir o leitor no ambiente multifário da sociedade moderna ("Nosso tempo") ou da consciência dilacerada do sujeito lírico ("Rola mundo").

A escala temática do livro também é marcada pela amplitude. Encontramos poemas sobre a própria poesia ("Consideração do poema", "Procura da poesia"), a subjetividade do eu lírico ("Carrego comigo", "Indicações"), o tempo em suas mais diversas modalidades ("Passagem da noite", "Nosso tempo", "Idade madura", "Desfile"), o medo ("O medo"), o amor ("O mito"), a família ("Como um presente", "Retrato de família"), a morte ("Morte no avião", "Morte do leiteiro"), o trabalho ("Noite na repartição"), a guerra ("Carta a Stalingrado", "Telegrama de Moscou”), a obra de outros artistas ("Mário de Andrade desce aos infernos", "Canto ao homem do povo Charlie Chaplin"), entre outros. Esses e outros temas aparecem frequentemente entrelaçados, em uma coletânea em que predomina o poema longo, que favorece uma atitude meditativa e reflexiva do sujeito poético diante dos objetos, de si mesmo, do mundo e da linguagem.

Embora se possa, como se fez até aqui, dividir a organização do livro entre variedade rítmica, temática, de registros e de procedimentos, é preciso entender, contudo, que Drummond conjuga todos esses elementos em uma poética própria que visa englobar, o quanto pode, a complexidade de seu momento histórico. Carpeaux formulou essa questão de modo preciso: “A poesia do 'tempo presente', transformando qualquer 'assunto' em matéria poética, não é exclusiva, é inclusiva. Transforma tudo em 
conceito poético". ${ }^{1}$ Ao ambicionar uma poesia em sintonia com os dinamismos profundos de um momento de radicais transformações históricas, sociais e culturais como foi o da Segunda Guerra Mundial, vista a partir da perspectiva do modernismo brasileiro, Drummond refina o seu instrumento ao máximo, não para torná-lo o mais poético possível como se a poesia fosse o resultado de uma especialização estanque, autocentrada e separada do mundo; ao contrário, o poeta procura elaborar uma linguagem em que o máximo de reflexão poética seja simultaneamente parte ativa da realidade em que ela se insere. Trata-se de um difícil compromisso entre uma literatura de experiência, em contato direto com o real, e uma poesia autoconsciente, fiel ao "reino das palavras". 2

O engajamento do livro de 1945, então, depende contraditoriamente do filtro da linguagem, do poder autorreflexivo de sua autonomia. Esse aspecto contraditório, entretanto, remete à vitalidade dessa poética, da inquietação constante que faz parte do seu processo compositivo. Assim Gledson descreve a posição dessa poesia diante do mundo: "A poética inteira de Drummond em A rosa do povo - nunca é demais ressaltar a importância deste fato - baseia-se na sua confiança de que os poemas são formas vivas que refletem as formas vivas do mundo objetivo: a rosa do povo, concretamente". ${ }^{3}$ A porosidade entre poesia e realidade, entre poeta e mundo, coloca sujeito lírico e linguagem em situação, como participantes dos fenômenos que os poemas do livro elaboram e expressam. As características de Drummond - ironia, ceticismo, autocrítica - convivem aqui com um momento excepcional de autoconfiança no sujeito lírico e na sua capacidade de contribuir para a transformação social. ${ }^{4}$ Ao fundir sujeito, poesia e sociedade em uma mesma poética, cuja variedade de meios expressivos espelha o propósito englobante do livro, Drummond procura encerrar em $A$ rosa do povo uma totalidade, uma espécie de suma de sua poesia até então, do modernismo literário, da sociedade brasileira e da virtualidade de uma revolução socialista mundial. O resultado, em termos poéticos, desse esforço pode ser lido no julgamento consensual da crítica sobre a posição do livro na obra do poeta. Para Merquior, trata-se da "obra central da época de consolidação do modernismo", 5 Antonio Candido a chama de "culminância lírica", 6 Iumna Simon de "ápice", 7 por fim, para citarmos apenas uma amostra, John Gledson julga essa "coletânea central” de Drummond "o momento-chave de sua obra". ${ }^{\circ}$

Tal posição não é isenta de contradições. Ao visar a síntese entre sujeito, palavra e mundo, entre poesia e sociedade, entre processo social brasileiro e revolução comunista global decorrente da Segunda Guerra Mundial, o livro se desdobra em diversas frentes, assume a assombrosa variedade descrita

\footnotetext{
${ }^{1}$ CARPEAUX, Otto Maria. Ensaios reunidos, 1942-1978. Rio de Janeiro: UniverCidade; Topbooks, 1999. v. I. p. 440. Talarico, em estudo recente, fala em "sistema integrativo" (TALARICO, Fernando B. F. História e poesia em Drummond. A rosa do povo. São Carlos, Edusc; São Paulo: Fapesp, 2011. p. 75). Segundo Antonio Candido, "é preciso considerar também que a sua maestria é menos a de um versificador que a de um criador de imagens, expressões e sequências, que se vinculam ao poder obscuro dos temas e geram diretamente a coerência total do poema, relegando quase para segundo plano o verso como unidade autônoma" (CANDIDO, Antonio. Vários escritos. São Paulo: Duas Cidades; Rio de Janeiro: Ouro sobre Azul, 2004, p. 96).

${ }^{2}$ A relação entre fechamento e abertura do discurso poético é analisada por SIMON, Iumna M. Drummond: uma poética do risco. São Paulo: Ática, 1978.

${ }^{3}$ GLEDSON, John. Poesia e poética de Carlos Drummond de Andrade. São Paulo: Duas Cidades, 1981. p. 196. Em outra chave, leia-se SAID, Roberto. A angústia da ação: poesia e política em Drummond. Curitiba, Edufpr; Belo Horizonte, EDUFMG, 2005, que aborda "os impasses e as aberturas deflagrados pelo encontro entre o campo literário e o político, entre a arte e o poder", p. 14.

4 “... o ceticismo e a ironia congênitos de sua obra (...) [s]ão aceitos e transcendidos dentro da própria confiança. É um momento breve" (GLEDSON, John. Poesia e poética de Carlos Drummond de Andrade, cit., p. 163).

${ }^{5}$ MERQUIOR, José Guilherme. Verso universo em Drummond. Rio de Janeiro: José Olympio, 1975. p. 98.

${ }^{6}$ CANDIDO, Antonio, op. cit., p. 70.

${ }^{7}$ SIMON, op. cit., p. 59.

${ }^{8}$ GLEDSON, op. cit., p. 163.
} 
anteriormente e se apresenta ao leitor e à crítica como um desafio ou como um enigma: se é possível circunscrever os elementos constitutivos da obra, elencar os seus procedimentos formais, reconhecer os seus desígnios, ainda assim não se consegue apreender a complexidade do livro, as direções diversas e contraditórias para onde nos levam a leitura dos poemas - para a família, para o Brasil ou para o mundo; para a atmosfera noturna ou para a alvorada; para o mundo vivido ou para o reino das palavras; para a abertura ou para o fechamento do discurso? Como captar o ritmo profundo que subjaz aos poemas do livro e justifica que eles sejam apresentados como componentes de uma unidade (o livro A rosa do povo) ou, ainda, como uma totalidade?

Antes de descrever o percurso de leitura que este texto adotará, é preciso reconhecer que a complexidade do livro se apresenta como uma teia de interconexões, em que certos temas, formas, registros, gestos e atitudes se repetem ao longo do livro, enquanto outros aparecem poucas ou uma única vez. Assim, por exemplo, no plano temático, a noite está mais presente do que a manhã e a tarde, cujas aparições são menos frequentes; dentre as possibilidades rítmicas, o poema em que predomina o verso octossílabo aparece uma única vez, em decassílabo algumas, em redondilha e em verso livre muitas; na esfera gestual, o gesto de desfalecimento melancólico disputa o espaço com a euforia transformadora poema a poema; no plano das atitudes, a confiança na vida das palavras por vezes se inquieta e se exaspera diante do "vasto mundo", cujo acesso é mediado, entretanto, pela condição fria e silenciosa das palavras "em estado de dicionário" etc. É como se o leitor precisasse, para o entendimento geral do livro, orientar-se dentro de uma enumeração caótica, não somente no plano do verso mas também no plano compositivo de um livro de poemas, tendo em vista que essa enumeração caótica se instala no interior de uma rigorosa arquitetura, em que grupos temáticos e formais fixam a integralidade da obra. Para dar apenas alguns exemplos, o tema da própria poesia nos dois poemas iniciais, as duas homenagens, - uma a um poeta brasileiro outra a um artista internacional - ao fim do livro, a organização sequencial dos poemas sobre a guerra, o grupo de oitos poemas curtos em sequência (de "Áporo" a "Equívoco”, com a exceção de "Vida menor”, que, no entanto, se une aos demais pela temática do "fechamento do discurso").

Assim, se não se pode estabelecer um único princípio que esclareça em um mesmo olhar, simultaneamente e com a mesma força, a totalidade dos poemas, é possível tecer conexões de diversos tipos ao longo do livro: temáticas, formais, de atitudes, de gestos, de registros etc. Dentre as muitas conexões possíveis, este ensaio escolheu algumas, de acordo com a sua hipótese de leitura, a culpa social, a expiação noturna e a relação entre morte e vida das palavras, todos ligados a uma conexão maior: o processo expiatório, que será explicado e desenvolvido mais adiante. ${ }^{9}$ Tenho consciência, contudo, que mesmo confiando no amplo poder explicativo dessa conexão proposta, ela não alcançará a mesma força em relação a todos os poemas. Diante dela, o que quero demonstrar é fato de que o livro de Drummond de 1945 possui um processo que, se não o explica integralmente, pode dar conta de sua significação e sentido estético e social em uma perspectiva que busque entender a dialética entre modernismo e engajamento.

\section{Culpa e Autodestruição Ritual}

Uma das conexões que mais chama a atenção no livro, sobretudo pelo aparente contraste com o momento de confiança representado pelo engajamento social, é a da figuração da morte simbólica

\footnotetext{
${ }^{9}$ Uma conexão que chama a atenção pelo inusitado, mas que não será abordada por este texto, é a presença-chave do inseto em alguns poemas ("Rola mundo", “Áporo", "Economia dos mares terrestres”, "Idade madura”).
} 
do sujeito lírico, presente em poemas como "O poeta escolhe seu túmulo", "Movimento da espada", "Morte no avião", "Os últimos dias", “Assalto". ${ }^{10}$ Porém, como veremos, a morte simbólica do sujeito lírico está conectada com um processo mais generalizado pelo livro, pelo qual a vida, tomada em sentido amplo, sofre uma depuração crítica tão radical que ela só pode se renovar após ser ritualmente destruída. Esse processo por um lado redime a vida de seus constrangimentos histórico-sociais, por outro, liberta as potencialidades transformadoras presentes no sujeito lírico, no Brasil e no mundo. Alguns momentos de A rosa do povo desnudam essa questão, por exemplo, em "Uma hora e mais outra", os versos "pois a hora mais bela/surge da mais triste", ou em "Morte do leiteiro", em que o sangue do inocente morto se une ao leite derramado para redimir, pelas cores da aurora, o crime reconhecido, ou ainda em "Carta a Stalingrado", em que a cidade-símbolo do combate se torna mais forte pela própria destruição: “... pois que entre as ruínas/outros homens surgem, a face negra de pó e de pólvora,/e o hálito selvagem da liberdade". ${ }^{11}$ Antonio Candido, referindo-se a "Versos à boca da noite", chamou esse movimento de "redenção pela poesia" e conclui sobre a poesia de Drummond: "assim vemos a sua obra constituir-se na medida em que opera a fusão dos motivos de morte e criação (negação e afirmação)". ${ }^{12}$ A essa operação, funcionando em um livro como $A$ rosa do povo, eu chamo de processo expiatório, e o entendo como uma orientação histórica e materialista para a dimensão mítica do ciclo morte-ressurreição implicado nessa redenção.

As implicações histórico-sociais do sujeito lírico drummondiano de $A$ rosa do povo recebem um tratamento direto, mas nem por isso menos elaborado poeticamente, em “A flor e a náusea". Os dois versos iniciais "Preso à minha classe e algumas roupas/vou de branco pela rua cinzenta" fazem o leitor tomar contato simultaneamente com o eu lírico e com a ação do poema. A apresentação é direta e simbólica, já que as cores não descrevem apenas o cenário mas também criam a sua atmosfera, em que a eventual pureza psicológica do eu lírico se confronta com as ruas tristes, povoadas, como se dirá no verso seguinte, por "melancolias, mercadorias". A "classe" do poeta possui uma polissemia inicial, em que pode significar "elegância”, "bons modos”, "educação" ou "classe social”, mas a continuação do poema acaba por determinar essa última acepção como correta, não apenas pelas referências ao mundo do capital (das "mercadorias") mas significativamente pelas infrações às boas normas de conduta lexical ao longo dos versos: "fezes" (v. 8), "vomitar" (v. 15), "crimes" (v. 22), "ódio" (v. 31), palavras que certamente destoam das normas e práticas da elegância e dos bons modos. Contudo, antes de especificar o que significa a classe social à qual o sujeito lírico está preso, é importante verificar a natureza formal do poema, cuja construção esclarece a força expressiva dos seus versos.

O poema em versos livres se destaca pelas suas frases curtas e diretas, em que predomina a proporção de uma frase por verso. Além disso, alterna afirmações (com exceção das duas perguntas dos versos 4 e 5) sobre o próprio sujeito lírico e sobre o mundo, entrelaçando os problemas do sujeito com os problemas do mundo: "O tempo pobre, o poeta pobre/fundem-se no mesmo impasse" (v. 9-10). Ressalte-se que essa pobreza é essencialmente moral, vinculada a "fezes" e "maus poemas", e não à pobreza de uma posição social materialmente precária, já que o poeta está preso a outra classe, justamente, como veremos, à classe que lhe macula moralmente. Os conteúdos dos versos são

\footnotetext{
${ }^{10}$ Sobre "Assalto", dirá John Gledson: "No fim, o viajante recolhe os fragmentos do passado - o "homem encontrado morto' é ele [o poeta], é claro - e joga-os pela janela" (GLEDSON, op. cit., p. 179).

${ }^{11}$ Esse tema está desenvolvido em PASINI, Leandro. A apreensão do desconcerto: subjetividade e nação na poesia de Mário de Andrade. São Paulo: Nankin, 2013. p. 252-255.

${ }^{12}$ CANDIDO, op. cit., p. 73.
} 
justapostos de acordo com os movimentos psicológicos, em um ritmo de arrancos, entre confessional e exaltado, frequentemente exasperado, em um poema em que até as duas últimas estrofes (v. 44-48) apresenta uma respiração agitada, irritada. O poeta cria um cenário urbano corrompido, desalentador, e coloca o sujeito lírico dentro dele, assediado e inconformado diante dessa situação, da qual no entanto faz parte e até ajudou a criar: "Crimes da terra, como perdoá-los/Tomei parte em muitos, outros escondi” (v. 22-23). Contudo, o clímax do poema, que o divide em duas partes, é o verso "Uma flor nasceu na rua!” (v.34), no qual a imagem simbólica da flor fornece as possibilidades de contestação e resistência ao mundo descrito na parte anterior do poema. Porém, quero me deter na estrofe que antecede ao nascimento da flor:

Pôr fogo em tudo, inclusive em mim.

Ao menino de 1918 chamavam anarquista.

Porém meu ódio é o melhor de mim.

Com ele me salvo

e dou a poucos uma esperança mínima.

(v. 29-33)

O que chama a atenção nesses versos é o surgimento de referências autobiográficas do sujeito empírico Carlos Drummond de Andrade. Dois fatos relativamente anedóticos da vida do homem Drummond passam a constituir um material simbólico do poeta, que os transpõe a um poema central do livro A rosa do povo, como "A flor e a náusea”, mas sem eliminar a reminiscência empírica. Em 1918, o então adolescente Carlos Drummond se diz anarquista para colegas e professores do colégio jesuíta "Anchieta", em Nova Friburgo. Por caçoada dos colegas, fica-lhe o apelido "anarquista", que, entretanto, agrava sua situação quando é expulso do colégio por insubordinação mental, por discordâncias com os professores padres. ${ }^{13}$ A prática de "incendiário" igualmente se liga a eventos de juventude, em que os jovens Drummond e Pedro Nava tentavam atear fogo na casa de "bonitas moradoras" para em seguida providencialmente apagar o fogo e atrair para si a atenção das moradoras. ${ }^{14}$ Ultrapassando o elemento anedótico, o que o crítico pode ver aí é a sobreposição propositadamente híbrida entre o sujeito empírico e o sujeito poético, que não chegam a se confundir, mas cujas fronteiras se tornam movediças, em que o sujeito empírico investe o sujeito lírico com fatos autobiográficos simbolicamente ressignificados na unidade da forma poética.

Essa estrofe ainda é notável por deixar claro, no interior da composição poética, o processo pelo qual a flor nasce na rua. Ao buscar uma síntese para resistir ao mundo corrompido, o poeta propõe-se uma (auto)aniquilação feroz: "Pôr fogo em tudo, inclusive em mim", lembrando em seguida seu atributo/ apelido "anarquista". Porém o que vem em seguida é mais importante, pois o poeta enfatiza que, menos que anarquismo, seu atributo essencial é o ódio, e é por meio dele que é possível a salvação e uma “esperança mínima”. Salvar-se contraditoriamente pelo ódio é o equivalente de buscar a criação pela via da (auto)destruição, por um fogo purificador que não poupa nem mesmo o sujeito incendiário. $\mathrm{O}$ surgimento da flor em seguida a esses versos não é arbitrário, antes, a flor nasce como uma consequência desses versos: a esperança presente na flor é o resultado da implacável destruição purificadora do sujeito lírico e do mundo que lhe corresponde.

O ódio a si mesmo corresponde ao fato de o sujeito lírico estar "preso a uma classe" e, nesse sentido, é um desdobramento da culpa social. Mário de Andrade já diagnosticara, em carta de 11 de agosto

\footnotetext{
${ }^{13}$ Drummond relata esse caso em Tempo, vida, poesia (ANDRADE, Carlos Drummond de. Prosa seleta. Rio de Janeiro: Nova Aguilar, 2003, p. 1222-1223) e também no poema "Segundo Dia", de Esquecer para lembrar - Boitempo III (1979). ${ }^{14}$ ANDRADE, Tempo, vida, poesia, op. cit., p. 1233-1234.
} 
de 1942, esse "violento ódio que tem o poeta de si mesmo" em Sentimento do mundo, decorrente da "uma raivosa consciência de sua própria desumanidade", cujo desdobramento em culpa será historiado por Vagner Camilo em Drummond: Da Rosa do Povo à Rosa das Trevas. ${ }^{15}$ Antonio Candido observa que: 'No importante poema 'A flor e a náusea', a condição individual e a condição social pesam sobre a personalidade e fazem-na sentir-se responsável pelo mundo malfeito, enquanto ligada a uma classe opressora. O ideal surge como força de redenção e, sob a forma tradicional de uma flor, rompe as camadas que aprisionam". ${ }^{16}$ É estritamente necessário, não obstante, notar que essa redenção se faz pela destruição de um sujeito lírico específico, vinculado a uma classe específica e a um momento histórico específico em nível nacional e mundial. A confiança demonstrada por Drummond em parte substancial do livro de 1945 está estruturalmente vinculada à conjuntura dos anos 1942-1945, em que a vitória sobre o fascismo italiano e o nazismo alemão corresponderia à vitória sobre o autoritarismo do Estado Novo no Brasil, e que poderia ser complementado pela expansão global do comunismo a partir do sucesso da União Soviética na Segunda Guerra. Portanto, a singularidade de $A$ rosa do povo na obra poética de Drummond se deve ao fato de que nenhum outro livro do poeta se expôs tanto à necessidade de um desdobramento histórico para que os seus poemas tivessem a pertinência projetada pelo poeta, ao mesmo tempo em que talvez em nenhum outro ele empenhou tão integralmente os seus recursos poéticos, a sua visão de mundo e a força utópica presente em seu material. Esse livro de poemas, então, está íntima e voluntariamente vinculado ao movimento da história, e não a uma evolução poética tomada em abstrato, como se a oeuvre de Drummond se compusesse em uma lógica exclusivamente monadológica.

Como se vê, o entendimento de uma imagem poética, a posição da "flor" em "A flor e a náusea", a relação com a estrofe anterior e a conexão desta com os versos iniciais do poema nos levaram ao modo como o livro foi concebido, o que, por sua vez, nos encaminhou para a relação de $A$ rosa do povo com o seu contexto histórico-social. Também no poema foi percebida a sobreposição de elementos do sujeito empírico sobre o sujeito lírico, criando a heterogênea persona poética do livro. Assim, tornase fundamental um breve excurso externo à obra para a especificação de alguns de seus elementos internos fundamentais. Em seu diário O observador no escritório, Drummond escreve em 12 de março de 1945: "Deixei ontem o meu posto no gabinete de Capanema. Desfecho natural da situação criada pela volta das atividades políticas no país." ${ }^{17}$ Ao longo desse ano, o poeta visita Luís Carlos Prestes, vincula-se ao Partido Comunista, trabalha na redação do jornal Tribuna Popular, anota uma série de hesitações quanto à sua vocação para a atuação política ${ }^{18}$ e, por fim, se afasta do jornal e do Partido, devido a discordâncias quanto aos seus direcionamentos. Junto da finalização de $A$ rosa do povo, que foi publicada em dezembro de $1945,{ }^{19}$ Drummond buscava então empenhar-se diretamente na luta política, dentro da esfera intelectual, mediado pela ação do Partido Comunista. Independentemente

15 SANTIAgO, Silviano (Org.). Carlos \& Mário. Correspondência de Carlos Drummond de Andrade e Mário de Andrade. Rio de Janeiro: Bem-Te-Vi, 2002. p. 480. Ver também capítulo "Drummond Héautontimorouménos: Culpa Social", de CAMILO, Vagner. Dummond: da Rosa do Povo à Rosa das Trevas. São Paulo: Ateliê Editorial, 2011. p. 243-26. Merquior também comenta: “o realismo social, o novo historicismo do 'sentimento do mundo' não suprimem outros domínios emocionais. O sentimento de culpa em particular” (MERQUIOR, José Guilherme. Verso universo em Drummond, cit., p. 89).

${ }^{16}$ CANDIDO, op. cit., p.78.

${ }^{17}$ ANDRADE, Carlos Drummond de. O observador no escritório. Prosa seleta. Rio de Janeiro: Nova Aguilar, 2003. p. 979.

${ }^{18}$ Como se pode notar nas seguintes citações de $O$ observador no escritório: "falta alguma coisa na minha vontade de atuar politicamente: falta precisamente a vontade, a garra, a paixão; é uma atitude intelectual, contra a minha natureza" (p. 982). "Resta o problema da ação política em bases individualistas, como pretende a minha natureza" (p. 983).

${ }^{19}$ Essa informação consta na p. 221 da primeira edição de A rosa do povo (José Olympio, 1945). 
dos conflitos e contradições gerados pela ação política, das futuras atitudes do poeta e dos labirintos da política partidária do período, importantes em si, mas que não caberiam no espaço deste ensaio, o que quero ressaltar é a coerência com que Drummond compunha a sua atuação, integrando engajamento político e poético, sem desrespeitar a especificidade da poesia e buscando articular uma visão particular de si e do Brasil.

É interessante notar, nesse contexto, a presença de Drummond em um livro que se tornou referência na sociologia da literatura brasileira, Intelectuais e classe dirigente no Brasil (1920-1945) (1979), de Sérgio Miceli, cujo argumento central procura denunciar os custos políticos do projeto modernista, vinculando a sua produção literária ao fenômeno sobredeterminante da "cooptação", que remunerava os intelectuais como funcionários públicos e garantiria dessa forma a sua fidelidade ao autoritarismo do Estado Novo. ${ }^{20}$ Embora assuma uma atitude "iconoclasta" diante do modernismo brasileiro, filiando-se à sociologia da arte bourdiana, cuja perspectiva é externa à obra literária e visa antes a denúncia dos seus meios políticos de legitimação, Miceli ampara a arquitetura de seu argumento central em trechos extraídos da obra de Drummond. O livro tem como epígrafe três trechos de poemas de Drummond: "Os bens e o sangue", "Confidência do itabirano" e "Explicação". O Capítulo III, "Os intelectuais e o Estado", em que o tema da "cooptação" ganha mais força, é pautado por um longo trecho da crônica sobre o escritor funcionário público, "A rotina e a quimera" (publicada em Passeios na ilha, 1952), mesma crônica com que esse capítulo se encerra, dando fecho à parte argumentativa da obra. Ao iniciar e encerrar o seu argumento com Drummond, percebemos que, se por um lado Miceli se ancora na autoconsciência da obra drummondiana para constituir o seu objeto de estudo, por outro precisa desautorizar e "denunciar" essa mesma obra como cooptada para manter a sua iconoclastia sociológica. A dimensão intelectual e reflexiva da poesia e da crônica de Drummond é então simultaneamente absorvida e rechaçada, com prejuízo igualmente simultâneo para o entendimento de Drummond e da obra de Miceli. Tomando a direção contrária desse (falso) conflito, é preciso ler a presença de Drummond em Intelectuais e classe dirigente no Brasil (1920-1945) a contrapelo, e ver aí a dimensão intelectual de Drummond, capaz de articular na poesia e na crônica a relação entre poesia e poder, entre literatura e sociedade no Brasil, incorporando em sua obra o mesmo dilema do sociólogo.

Assim, o poeta caminha pelo espaço da história brasileira: ele parte do país dos Andrades ("No País dos Andrades") e retorna a este com o insólito boi de "Episódio"; encena o drama, um tanto farsesco, do funcionário público em "Noite na repartição", e cria o amplo afresco mural da vida urbana contemporânea ao livro em "Nosso tempo". ${ }^{21}$ Com isso, Drummond especifica um tempo e um espaço, bem como a sua posição dentro dele, fundindo poesia e conhecimento ou, como diz Merquior: "a interpretação lírica se alimenta de uma espécie de análise sociológica bem sua". ${ }^{22}$ Ao determinar a configuração histórico-social do sujeito lírico, há a confluência do sujeito empírico e do sujeito histórico determinado, e olhar para si, dessa forma, é também olhar para o mundo. O descendente da oligarquia rural decadente que se torna público vinculado ao regime autoritário do Estado Novo: eis um sujeito histórico que deve morrer para que a transformação social possa acontecer, mas não apenas como sujeito, e sim como representante e símbolo da classe a que está preso. É essa morte simbólica que lemos em "Movimento da espada".

\footnotetext{
20 "Diante dos dilemas de toda ordem com que se debatiam por força de sua filiação ao regime autoritário que remunerava seus serviços, [os escritores] buscaram minimizar os favores da cooptação se lhes contrapondo uma produção intelectual fundada em álibis nacionalistas" (MICELI, Sérgio. Intelectuais e classe dirigente no Brasil (1922-1945). São Paulo: Difel, 1979. p. 129).

${ }^{21}$ Haverá também o tempo da consciência perpassado pela história brasileira, sobretudo em ambientações noturnas, em poemas como "O Medo", "Anoitecer", "Uma hora e mais outra". Abordaremos esse tópico adiante.

${ }^{22}$ MERQUIOR, José Guilherme. Verso universo em Drummond, op. cit., p. 78. Merquior também fala em "historicismo lírico" (p. 78), "realismo social de Drummond" (p. 89) e "macrorrealismo drummondiano" (p. 93).
} 


\section{Movimento da espada}

Estamos quites, irmão vingador.

Desceu a espada

e cortou o braço.

Cá está ele, molhado em rubro.

5

Dói o ombro, mas sobre o ombro

tua justiça resplandece.

Já podes sorrir, tua boca

moldar-se em beijo de amor.

Beijo-te, irmão, minha dívida

10 está paga.

Fizemos as contas, estamos alegres.

Tua lâmina corta, mas é doce,

A carne sente, mas limpa-se.

O sol eterno brilha de novo

15 E seca a ferida.

Mutilado, mas quanto movimento

em mim procura ordem.

$\mathrm{O}$ que perdi se multiplica

e uma pobreza feita de pérolas

20 salva o tempo, resgata a noite.

Irmão, saber que és irmão,

na carne como nos domingos.

Rolaremos juntos pelo mar...

Agasalhado em tua vingança,

25 puro e imparcial como um cadáver que o ar embalsamasse,

serei carga jogada à ondas,

mas as ondas, também elas, secam,

e o sol brilha sempre.

Sobre minha mesa, sobre minha cova, como brilha o sol!

Obrigado, irmão, pelo sol que me deste,

na aparência roubando-o.

Já não posso classificar os bens preciosos.

Tudo é precioso...

e tranquilo

como olhos guardados nas pálpebras.

O tom dos versos, no geral curtos, é de tranquilidade, com exceção dos versos da última estrofe, em que há a sugestão de júbilo, com a exclamação inicial e a reiteração da preciosidade dos bens recebidos, como um tipo de benção in extremis. Há uma respiração calma, como de alívio, ordenando o ritmo dos versos, análoga ao seu conteúdo, que descreve a mutilação e a morte do sujeito lírico como um ato de justiça do irmão vingador. "Movimento da espada" expõe um sujeito histórico que não traz traços do sujeito empírico Drummond, traz antes a generalidade do sujeito portador da culpa histórica. O poema resolve questões que ficaram sem soluções em dois outros poemas de Drummond: o beijo (v. 8-9), que era uma expectativa de compreensão no final de "O operário no mar" (Sentimento do mundo, 1940), é agora plena comunhão; a carne suja de "A mão suja" (José, 1942), ${ }^{23}$ que o poeta deseja cortar

\footnotetext{
${ }^{23}$ A conexão entre esses poemas foi estabelecida por CAMILO, Vagner. Dummond, op. cit., 247-256. Merquior nota, ao comentar "Movimento da espada": "uma vez cortado o braço 'sujo', o eu do poeta pode aceder à justiça e à fraternidade" (MERQUIOR, José Guilherme. Verso universo em Drummond, op. cit., p. 89).
} 
na esperança de que outra surja no lugar, é aqui cortada para provocar a mutilação irrevogável: "a carne sente, mas limpa-se" (v. 13), e o sujeito lírico mutilado primeiro rola sobre o mar, depois sobre a cova, em seguida sob a tranquilidade das pálpebras fechadas. A mutilação seguida de morte concilia os problemas anteriores da culpa social, mas o seu preço é a vida simbólica do sujeito lírico. Contudo, esse preço, ou melhor, essa dívida, é paga com alegria solar, em que o eu lírico se purifica (v. 25) em sacrifício ritual, para que a igualdade se estabeleça sob o rigor da morte, mas, igualmente, consagrando o sujeito que cumpriu a expiação pelos seus males. Ele sela a fraternidade por um processo expiatório, por um sacrifício ritual rigorosamente encenado.

É preciso notar o sentido de profunda humanidade e solidariedade que coloca em marcha o processo de autodestruição (e do reconhecimento da culpa). Trata-se de um processo necessário para que a fraternidade possa surgir: "A redenção pela mutilação de um eu insatisfatório aparece em tonalidade sangrenta e triunfal [em] 'Movimento da Espada', onde o sacrifício do eu culposo condiciona o acesso à solidariedade, que é a humanidade verdadeira". ${ }^{24}$ Abre-se assim um tipo de dialética da culpa, em que, ao chamar-se sobre si todo o peso da (má) consciência moral da classe opressora, ao amplificar a sua subjetividade histórica e torná-la símbolo de toda uma classe, o autointitulado representante dessa classe e portador de sua culpa expõe-se a um processo expiatório que é, ele mesmo, o penhor da solidariedade, transformando-se em uma figuração poética dos pressupostos da revolução social brasileira. Drummond consegue assim transformar o "violento ódio de si mesmo" em uma autocrítica impiedosa, em que a união desse ódio com a expiação social pode anunciar o aparecimento de um novo sujeito histórico, um "irmão vingador", antagonista e redentor do eu lírico.

O eu lírico de Drummond foi sempre construído em sua poesia sob o signo da inadequação, do gauche, do triste, do suicida, do solitário melancólico. Contudo, essas características adquirem em $A$ rosa do povo a capacidade de se transformar em uma forma contraditória de engajamento social. A solidão, ${ }^{25}$ ressentindo em seu isolamento a culpa e a carga histórica de uma classe, pode comunicar-se como expiação. E a inadequação, aceita em sua fragilidade e transformada em humilde ternura, pode universalizar o sujeito gauche na figura de Carlito, o "noturno cidadão de uma república enlutada" ("Canto ao homem do povo Charlie Chaplin” II, v. 10-11), “o que não está de acordo e é meigo" (V, v. 40). As "sugestões alimentícias" (III, v. 1) dos filmes de Chaplin vão fornecer a Drummond mais uma imagem do artista como figura sacrifical diante da desigualdade social. Aos versos "Não há muitos jantares no mundo, já sabias,/e os mais belos frangos/são protegidos em pratos chineses por vidros espessos" (III, v. 14-16) o poeta contrapõe essa consciência social-alimentar de Carlito à transformação do próprio personagem em comida: "Então te transformas/tu mesmo no grande frango assado que flutua/ sobre todas as fomes, no ar; frango de ouro/e chama, comida geral/para o dia geral, que tarda" (III, v. 25-29). ${ }^{26}$ Drummond procura apressar a vinda desse "dia geral", ou pelo menos orientá-lo, pelo sacrifício do sujeito lírico em "Movimento da espada", em que o sol, proporcionado pelo "irmão vingador", vela o sono dos justos sob as pálpebras tranquilas. Esse poema é o momento solar, luminoso, da expiação, que, contudo, possui igualmente um doloroso momento noturno.

\footnotetext{
${ }^{24}$ CANDIDO, op. cit., p. 75.

${ }^{25}$ Sérgio Milliet nota "a nua tristeza de uma solidão irremediável" (MILLIET, Sérgio. "A Rosa do Povo". Diário de Notícias, RJ, 03/02/1946. Reproduzido em ANDRADE, Carlos Drummond. Poesia 1930-1961. São Paulo: Cosac Naify, 2012, p. 975). "Se insisto no problema da solidão, é porque ele me parece não só a mola deste livro [Confissões de Minas] como de toda a poesia e mesmo da personalidade literária do Sr. Carlos Drummond de Andrade" (CANDIDO, Antonio. "Notas de crítica literária". Folha da Manhã, SP, 15/10/1944. Reproduzido em ANDRADE, Carlos Drummond. Confissões de Minas. São Paulo: Cosac Naify, 2011, p. 229).

${ }^{26}$ No filme Em busca do ouro (The gold rush, 1925), entre os minutos 22'37" e 23'16", ocorre a transformação de Carlito em frango, embora não assado, em um episódio de fome entre dois companheiros em uma cabana no Alaska.
} 


\section{Expiação Noturna}

Em "Passagem da noite", a noite do tempo cronológico se funde com a noite psicológica: "Sinto que somos noite,/que palpitamos no escuro" (v. 7-8), em que a dimensão noturna adquire uma consistência própria, que não é morte, nem dor, nem paz, mas uma coisa a um tempo específica e indefinida, na qual o sujeito lírico se dissolve plenamente. Essa imagem poderosa da noite, contudo, se desfaz sob o efeito natural do tempo, em que o dia, ao surgir, renova o gosto de viver, sentido como palpitação, fraternidade, amor, cercados por uma aura de vida que emana dos objetos. Também a manhã opera uma fusão do dia cronológico com o dia da consciência. A separação do poema em duas partes claramente distintas, criando uma oposição esquemática noite/dia, ainda que impregnada do movimento subjetivo, simplifica a dramaticidade do processo trevas/luz presente em outros momentos do livro, ${ }^{27}$ o que o enfraquece esteticamente como realização, embora a sua concepção seja forte e esteja presente em diversos momentos do livro.

A noite da consciência adquire uma elaboração mais incisiva em "Anoitecer", em que os acontecimentos vinculados à cronologia, expressos pela anáfora "É a hora em que...", "É a hora do...", "Hora de...", "É antes a hora...", não correspondem a eventos possíveis na ambientação urbana e psicológica do poema. Antes, o que ocorre nos versos é o advento de imagens soturnas, melancólicas, perturbadoras, cujo fecho no fim de cada uma das quatro estrofes do poema é outra anáfora: "desta hora tenho medo", com uma pequena variação de ênfase no último verso. Convém notar que a construção poética que se faz pela conjunção de ambientação lúgubre, repetição anafórica e desespero subjetivo associa-se à poesia católica da década de 1930, praticada exemplarmente por Augusto Frederico Schmidt. Drummond recupera esses elementos, que então já estavam inquestionavelmente anexados ao repertório da poesia modernista brasileira, e os reconfigura segundo a sua proposta em $A$ rosa do povo, fundindo nessa estética os elementos do cotidiano urbano, dando assim maior concretude à subjetividade desesperada. Tomado de forma isolada, o sujeito poético possui a generalidade do eu lírico da poesia católica de 1930, só que dotado de um desespero secular, e não religioso. Entretanto, situado no contexto do livro, ele se mostra como a exploração de um momento da subjetividade, do seu momento noturno ou, mais propriamente, do processo pelo qual a noite se instala no sujeito, daí o aspecto verbal incoativo de "anoitecer", que dá título ao poema. Os últimos versos do poema abrem essa possibilidade de interpretação do eu lírico no contexto do livro:

\footnotetext{
É antes a hora dos corvos, bicando em mim, meu passado, meu futuro, meu degredo desta hora, sim, tenho medo.
}

A vírgula no segundo verso da citação cria uma ambiguidade sintática que abre duas possibilidades de leitura da estrofe: na primeira, que seria a única, caso não houvesse a vírgula, os corvos bicam o passado, o futuro e o degredo do sujeito lírico; na segunda, passado, futuro e degredo seriam sintaticamente apostos de "corvos", simbolizando os agentes da dor do eu lírico e criadores da hora de medo. Seja como for, a punição descrita no poema, a imagem dos corvos se alimentando de um corpo ainda vivo remete a Prometeu e seu sacrifício pela humanidade. No entanto, o que se lê nos versos é menos a função redentora do mito do que o enfoque em seu instante aterrador, cujo resultado é "o medo", que será o título do poema

27 “A metáfora da luz que supera as trevas é uma constante na obra poética de Drummond, apresentando-se sob variados perfis e relações” (SIMON, op. cit., p. 124). 
seguinte do livro. Neste, o medo é sobretudo em fator de enclausuramento, que Antonio Candido chama de "sentimento de inumação em vida" e conclui: "Este tema, que se poderia chamar de emparedamento, manifesta uma opressão do ser que chega a assumir a forma de morte antecipada" 28 A noite e o medo são fatores de paralisação e consequente aniquilação do eu lírico, causando a sua morte prematura. A resposta de Drummond a essa questão em "Movimento da espada", como vimos, é menos evitar a morte simbólica do que ter a força para dirigi-la, orientá-la, transformá-la em um ritual expiatório. Para isso, é preciso dominar a noite, superá-la a partir de dentro.

Note-se que os dois artistas homenageados nos dois poemas finais do livro são capazes de fazer a vida surgir de dentro da noite. Na parte II de "Canto ao homem do povo Charlie Chaplin", Carlito é descrito como aquele cuja roupa é banhada pela noite, o personagem é "condenado ao negro" (v. 5), tornando-se o já citado "noturno cidadão de uma república enlutada"; no entanto, o rosto lunar, os olhos profundos e a boca calada, a sorrir, dissolvem a noite e trazem a aurora "para todos" (v. 29). Como apontou John Gledson: "Vindo das trevas, falando da solidão e do isolamento para os solitários e os derrotados, Chaplin estabeleceu uma linguagem que comunica a todos; vindo de um mundo alienado, domina essa alienação de dentro". ${ }^{29}$ Em "Mário de Andrade desce aos infernos", em uma referência um tanto enigmática da parte IV do poema, Drummond escreve que a rosa do povo foi anunciada por Mário "nas trevas": "O poeta, nas trevas, anunciou" (v. 7). Ficamos na dúvida se as trevas se referem à morte de Mário de Andrade, cuja obra, encerrada pela morte e vista agora em sua totalidade, anunciaria a rosa do povo, ou se a postura severamente autocrítica de Mário nos anos 1940, presente, por exemplo, na conferência “O Movimento Modernista" (1942), acrescida da atitude sacrificial constante na obra de $\mathrm{Mário}^{30}$ teriam anunciado e desabrochado a rosa do povo, símbolo e título do livro.

Para desenvolver, então, a questão final do poema "Anoitecer”, o sujeito lírico drummondiano precisa reconquistar seu passado, refazer-se dentro do tempo, para completar o ciclo prometeico prefigurado no poema. O passado, seja ele o que o corvo bica ou uma das encarnações do corvo, é sem dúvida um agente poderoso do medo, ele prende o sujeito à sua classe, funde-o ao tempo pobre e o sepulta nas determinações históricas que o geraram. O poema "Desfile" aborda diretamente o tempo e sua relação com o eu lírico. Ao colocar "o rosto no travesseiro" (v. 1), o poeta escuta o tempo fluir. Entretanto, o tempo flui no silêncio para trás, já que o eu lírico passa a ver-se em etapas anteriores de sua vida. Assim, embora sugira a atmosfera onírica, propícia à analogia livre e mesmo à escrita automática, o poema é rigorosamente ordenado, não apenas pelo ritmo em redondilha maior dos versos brancos mas igualmente pelo sentido linear do fluxo temporal. O eu lírico progressivamente volta a ser jovem: "fiquei mais moço" (v. 9), criança no ambiente do colégio (v. 25) e mesmo feto: "Mais longe, mais baixo, vejo/uma estátua de menino/ou um menino afogado" (v. 36-38). Depois disso, o poeta não vê "mais nada" (v. 39). Ressalte-se o ponto axial no poema em que morte e criação se confundem, quando o eu lírico, envolvido no ventre materno, se enxerga como "estátua" e "afogado", unindo assim regressus ad uterum e morte. A partir desse momento, em que, indiferenciado e primordial, nascimento e morte convergem, o poema retorna ao seu momento presente, em que a luz surge "no quarto em forma de túnel” (v. 40). Novamente, há referências ao longo do poema ao sujeito empírico

\footnotetext{
${ }^{28}$ CANDIDO, op. cit., p. 73.

${ }^{29}$ GLEDSON, op. cit., p. 205.

${ }^{30}$ Mário de Andrade fala da "constância coreográfico-dionisíaca que atravessa toda a minha poesia, e pra qual o Roger Bastide já chamou a atenção" (ANDRADE, Mário de. A Carlos Lacerda. In: PAES, José Paulo. Sobre "O Carro da Miséria”. Revista do Instituto de Estudos Brasileiros, n. 36. São Paulo: IEB, 1994. p. 181-182).
} 
Drummond: o jovem poeta que quer queimar casas (v. 15-16) e a criança na paisagem montanhosa e fria do colégio de Nova Friburgo (v. 25-29). O sujeito poético mais uma vez se compõe com características do sujeito empírico, criando a singularidade do enunciador de "Desfile". Ao recompor-se no tempo, a luz ilumina o quarto, o poeta se apalpa e reconhece em si uma peculiaridade: "Se eu morrer, morre comigo/ um certo modo de ver" (v. 47-48), reconhecendo, no dístico "Tudo foi prêmio do tempo/e no tempo se converte" a função formativa e imanente do tempo.

O poeta escuta o tempo e o ocupa, ${ }^{31}$ percebe-se a si mesmo como um elemento que flui no tempo e no qual o tempo flui, e que de certa forma pode no poema organizar o fluxo temporal e o sujeito dentro dele. Drummond alterna imagens de um silencioso fluir ("vento no cabelo" v. 8, "lamber de língua de cão/ na face" v. 22-23, "planta que se alonga" v. 54) com reminiscências autobiográficas que reconstroem a história de um indivíduo. Dois níveis imagéticos se estabelecem, desse modo, em "Desfile", cujo intuito é captar a frágil e quase imperceptível substância do que flui. Ao circundar a extensão temporal que abarca a sua vida, o enunciador do poema é capaz de configurar-se em comunhão com essa substância, que flui "como sangue" (v. 52), criando assim a convergência concreta, sanguínea, entre o que circula dentro e fora do sujeito lírico. O verso final "fecho os olhos, para ensaio" (v. 60) deixa em suspenso a palavra-título do poema, pois o mesmo "desfile" que orienta o andamento ritmado dos versos e das imagens é deslocado igualmente para fora do contexto do poema, já que o "ensaio" se faz de olhos fechados, o que constitui um plano que o poema não contempla; por isso, não se pode dizer de que matéria esse ensaio é feito e, por consequência, como seria o desfile para o qual se ensaia. Seja no sono, no sonho ou na morte, não sabemos como ocorre o ensaio; no entanto, vemos que ele é antecedido por uma coreografia prévia, em que tempo e sujeito se coordenam e de cuja interação desponta um certo modo de ver.

Portanto, a visão de mundo drummondiana se intensifica e se torna original na medida em que o sujeito do poema se individualiza. Assim, "Desfile" é peculiar nessa coletânea por filiar a especificidade e a singularidade do ponto de vista à autoconsciência de Drummond enquanto sujeito poético e sujeito empírico. Essa filiação torna-se ainda mais singular quando temos em mente a proposta engajada de $A$ rosa do povo. Vemos que, em vez de superar o lirismo individualista na direção de uma lírica social, Drummond define o seu engajamento social na medida em que a dimensão reflexiva de seu individualismo se amplifica ao máximo, ${ }^{32}$ ao se reconhecer como sujeito histórico, absorver a historicidade da sua posição de classe e de seu peso moral e figurar a sua destruição ritual. Tal densidade reflexiva, que caracteriza o engajamento de Drummond, não se faz então a despeito ou contra o indivíduo, mas por meio do indivíduo, que se amplifica em sua dimensão histórico-social, ultrapassa a contingência e se torna símbolo da expiação necessária da classe dominante brasileira e da realidade que lhe corresponde para que a vida, tirada metaforicamente do sujeito lírico, se multiplique menos mutilada e mais autêntica.

\section{Morte e Vida das Palavras}

A dimensão reflexiva demonstrada em A rosa do povo nos planos do sujeito lírico e do tempo está igualmente presente na sua relação com a palavra poética. Em “A flor e a náusea”, por exemplo, o poeta diz que "Sob a pele das palavras há cifras e códigos" (v. 12), por isso é vão que ele tente se

\footnotetext{
${ }^{31}$ John Gledson estudou a relação entre tempo e espaço em A rosa do povo: GLEDSON, op. cit., p. $174-187$.

32 O poema "Versos à boca da noite" dialoga com "Desfile" nesse sentido, ao dispor do decassílabo branco da lírica meditativa do romantismo como ritmo para tratar dos efeitos do tempo e da velhice sobre o eu lírico. Notável que a severidade do poema se torna furor quando o sujeito lírico, em pedaços, se dissolve pelo atlas (v. 49-52) e novamente a ordenação do tempo conduz o eu lírico para o "lenho dócil/um mergulho em piscina" (v. 61-62): despedaçamento e recomposição sob o signo da morte cujo resultado é "tal uma inteligência do universo" (v. 64), ou seja, uma reconfiguração singular da totalidade a partir de "um certo modo de ver".
} 
explicar aos "muros". Cifras e códigos, desse modo, no contexto do poema, prendem as palavras a uma classe e suas roupas tanto quanto o fazem com o sujeito lírico. Isso entraria, aparentemente, em contradição com a confiança na palavra poética demonstrada no primeiro poema do livro, “Consideração do poema", no qual o poeta afirma que "As palavras não nascem amarradas,/elas saltam, se beijam, se dissolvem,/no céu livre por vezes um desenho,/são puras, largas, autênticas, indevassáveis" (v. 5-8). Esses versos repõem no contexto de A rosa do povo aquele impulso da vanguarda poética que foi a defesa das “palavras em liberdade”. No entanto, que liberdade é possível quando a interioridade das palavras está dominada pelo tempo pobre, pelo relógio sujo, pelas melancolias e mercadorias? Será preciso, então, confrontar o potencial de liberdade das palavras com o dinamismo específico que lhes foi imposto pelo contexto histórico-social em que ela é utilizada. ${ }^{33}$ Focalizar a palavra em si, não como instrumento para algo que lhe é externo, mas como elemento autoconsciente de criação é o que faz o poeta em "Procura da poesia".

A princípio, "Procura da poesia", um dos poemas mais comentados de $A$ rosa do povo, parece entrar em franca contradição com o restante do livro. A sua defesa da imersão no "reino das palavras" (v. 33) é resultado de um procedimento de negação reiterada sobre diversos modos de fazer poesia, o que ocupa mais da metade do poema. No entanto, a impressão inicial que se têm é a de que o "não" do poema incide sobre parte significativa dos poemas de $A$ rosa do povo, senão vejamos: "Não faça versos sobre acontecimentos" (v. 1) contraria o acontecimento de "A flor e náusea": "uma flor nasceu na rua!” (v. 34); “As afinidades, os aniversários, os incidentes pessoais não contam” (v. 5) excluiria os poemas sobre Mário de Andrade e Chaplin, além de "Como um presente" e "Episódio"; "Nem me reveles teus sentimentos" (v. 10) eliminaria "Passagem da noite"; negar-se a cantar "os homens em sociedade" (v. 17) negaria também existência a "Nosso tempo"; "Não dramatizes" (v. 21) elidiria "Noite na repartição"; “... vossos esqueletos de família/desaparecem na curva do tempo" (v. 25-26) retiraria do livro "Retrato de família" e "Rua da madrugada"; e os exemplos poderiam continuar. ${ }^{34}$ Portanto, conclui-se que o problema central do poema não é tanto na presença de um tema ou outro, mas que a temática se sobreponha às palavras, as instrumentalize sem perceber que, se assim o fizesse, traria para o poema, voluntariamente ou não, o mundo corrompido de "A flor e a náusea" e "Nosso tempo", gerando, assim, apenas mais um dos "maus poemas" do tempo pobre.

As palavras possuem, então, a mesma historicidade do sujeito lírico, estão tão carregadas com peso da sociedade quanto ele. Como diz Iumna Simon: “a penetração no 'reino das palavras' tem por objetivo recuperar a vitalidade própria do signo linguístico, exaurida pelo atrofiamento determinado por um processo histórico que lhe imprime a marca do desgaste e da falsificação". ${ }^{35}$ Por isso, Drummond instaura em "Procura da poesia" uma atitude poética mediada pela negação e pela reflexão, buscando uma linguagem depurada do mundo como fato bruto. O preço dessa depuração é a mutilação simbólica que sujeito lírico e palavra sofrem: é necessário penetrar "surdamente" (v. 33) no reino das palavras, onde os poemas estão "sós e mudos" (v. 37). Aceder às "mil faces secretas sob a face neutra" (v. 50) envolve uma etapa de surdez e mudez, de paralisia, inércia e

\footnotetext{
33 “... o obscurecimento e a falsificação das palavras - desgastadas pelo uso e pelas amarras impostas pelo condicionamento histórico-social - servem como forma de encobrimento da realidade" (SIMON, op. cit., p. 165).

34 "Não recomponhas/tua sepultada e merencória infância" (v. 27-28) cortaria "Interpretação de Dezembro" do livro etc.

${ }^{35}$ SIMON, op. cit., p. 167. Note-se que, diante da poesia, "a vida é um sol estático" (v. 3), o que exclui a poesia da determinação temporal, do ciclo noite/dia e, por consequência, da história. Entendida no interior do caráter processual de "Procura da poesia", isso não significa que a poesia está fora da história e do tempo, mas que a poesia só pode se tornar verdadeira se romper, de algum modo, a sua participação na história tal qual foi constituída até esse momento, ou seja, se puder se despir dos "tempos sujos" ("Consideração do poema” v. 30) em que vive.
} 
silêncio, em que as próprias palavras precisam ser limpas de sua sedimentação histórico-social. No próprio poema, as palavras passam por um processo de depuração, indo da negação inicial a um estado diferente, em que ficam frias, neutras, limpas e enigmáticas, aptas, a partir de então, para ganhar e engendrar um novo sentido em um mundo novo. As palavras, então, sofrem um processo de autodestruição purificadora, expiatório, para poderem reviver potencialmente em um mundo transformado, revolucionado. O tratamento metapoético de Drummond acompanha então o mesmo desenvolvimento presente nos outros temas do livro aqui tratados: a culpa e a expiação noturna. Note-se que o poema não completa o rito sacrificial, deixando-o em estado latente, pois as palavras, "ermas de melodia e conceito" (v. 55), ou seja, radicalizando o seu processo de mutilação purificadora, "se refugiaram na noite" (v. 56), em uma noite certamente análoga à noite expiatória do restante do livro, e, letárgicas, seguem "num rio difícil e se transformam em desprezo" (v. 58). Embora potencialmente libertadas, as palavras ainda precisam ser despertadas; para isso, elas devem escapar ao mundo como ele realmente é e, por um rito depurador, alcançar o mundo como ele pode ser, um mundo recriado pelo critério da liberdade lúcida, tal qual demonstrada nos versos já citados de "Consideração do poema", mostrando que os dois poemas metapoéticos iniciais do livro não se opõem, ao contrário, um é a condição de possibilidade do outro.

Não estamos, assim, diante de uma poética mallarmeana, em que a obsessão pela palavra e as suas sugestões misteriosas, da "palavra como violação de um estado absoluto", ${ }^{36}$ buscaria um tipo de integração órfica com o universo. Antes, o poema contém uma conexão singular com o mito dionisíaco, em que a destruição ritual é um momento redentor em um ciclo morte-ressurreição, ou, no caso de Drummond, expiação-resssurgimento. A poética de Drummond de "Procura da poesia" não vira as costas ao mundo, antes o incorpora no contexto geral expiatório de $A$ rosa do povo. Como diz John Gledson: "Drummond distingue-se de Mallarmé pela sua crença de que as palavras e a poesia (que habita o 'reino das palavras') refletem a estrutura da realidade". ${ }^{37}$ Ao unir a palavra poética e o sujeito lírico em um mesmo processo expiatório, que prefigurariam uma homologia entre poesia e sociedade, A rosa do povo pode ser lida como o livro de um Brasil em processo de redenção no quadro mais amplo de uma revolução comunista mundial. Desse modo, o poeta procura inserir-se na atualidade do movimento histórico global com uma lucidez ímpar quanto à especificidade de sua experiência local em relação a essa ressonância universal. A busca por esse objetivo levou o poeta a lançar mão de todo o seu arsenal poético, alcançando uma espécie de consumação não somente de toda a sua obra até então mas também do modernismo brasileiro como um todo, abarcando em um único livro as suas formas, temas, registros, gestos, atitudes e ambições.

Isso nos coloca novamente diante do problema da relação entre engajamento e poesia no âmbito do modernismo global. A solução drummondiana de $A$ rosa do povo para essa questão pode ser descrita da seguinte forma: por sua autoconsciência, a poesia modernista se sente parte do mundo; no entanto, ela não tem força para, sozinha, transformar a realidade, o que restringe o seu potencial utópico. Consequentemente, quando a poesia atinge, por meio de sua autonomia e autorreflexão, o seu momento de maior lucidez, comprometimento com o mundo e ciência da história, ela conhece o limite de sua secularização e passa por uma transformação dialética. Ao reunir todas as suas forças para tentar transformar o mundo, a poesia, diante de sua impotência social efetiva, acaba por retornar às suas origens mágicas, mítico-rituais, momento em que se supunha que a palavra

\footnotetext{
${ }^{36}$ CANDIDO, op. cit., p. 93.

${ }^{37}$ GLEDSON, op. cit., p. 197. Para uma perspectiva oposta, ver SIMON, op. cit., p. 151: “'Procura da Poesia’ é uma proposta avessa à vontade catártica de expressão através do 'canto"”.
} 
tivesse o poder de modificar a realidade por meio de sua enunciação. Essa aporia presente em $A$ rosa do povo esclarece a um tempo a riqueza de sua acumulação literária, a sua posição de suma e síntese da poesia modernista brasileira, bem como o fracasso objetivo do seu engajamento social. A ausência de um agente social transformador complementar ao que foi figurado no livro expõe os limites históricos da sociedade brasileira de então, que não produziu um "irmão vingador" e, dessa forma, o restringiu à figuração literária do livro de Drummond de 1945. Contudo, A rosa do povo alcançou uma posição única na história da poesia brasileira ao unir experimentação poética, interpretação da realidade brasileira, engajamento social e história mundial, criando uma imagem dialética singular da relação entre as potencialidades poéticas da poesia modernista e as fraturas sociais brasileiras.

Recebido em: 22/06/15. Aprovado em: 21/01/2016 